
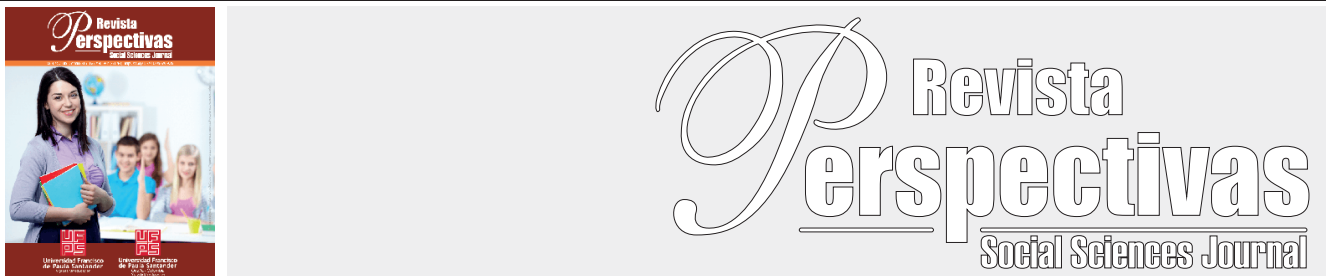

Original Article

https://doi.org/10.22463/0122820X.1793

\title{
Nomadic ethics and thoughtful ethics
}

\section{Ética nómada y ética reflexiva}

Jorge Eliecer Martínez-Posada ${ }^{1}$, Audin Aloiso Gamboa-Suárez ${ }^{2}$, Alicia Inés Villa ${ }^{3}$

'Doctor en Ciencias Sociales, jormartinez@unisalle.edu.co, ORCID 0000-0003-4377-6872,Universidad de la Salle, Bogotá, Colombia.

2Doctor en Ciencias Sociales, Niñez y Juventud, audingamboa@ufps.edu.co, ORCID 0000-0001-9755-6408, Universidad Francisco de Paula Santander, Cúcuta, Colombia.

${ }^{3}$ Doctora en Ciencias Sociales, alivilla@gmail.com, CIC/IdIHSC-UNLP, Argentina.

how to cite: Martinez, J., Gamboa, A. \& Villa, A. (2019). Nomadic ethics and thoughtful ethic. Perspectivas, $4(2)$, 64 79, 2019.

Received: June 27, 2018; Approved: October 03, 2018.

\begin{tabular}{ll}
\hline KBSTRACT \\
\hline Keywords: & $\begin{array}{l}\text { Speak of the "subject" and "ethics" today must start from a different place or a non-place that understands the } \\
\text { subject in his becoming and transformation, identifying him to recognize him, conceiving him as a subject } \\
\text { in transit, a nomadic subject, which can be reinvented in an ethical exercise that is reflective of himself and }\end{array}$ \\
Ethics & himself, without forgetting his constant encounter with the other. This article of reflection aims to make an \\
understanding and a journey through ethical developments, approaching a genealogy of it. Similarly, it tries to \\
Politics & relate to the construction of subjectivity from the intimate, the public and the private, as a modes of action of \\
Practice & the ethical in the subject and finally reflect on the transpositions of a nomadic ethic within multiple diasporas \\
& that allow a vision of modern ethics and possibility in the configuration of the subjects and their subjectivities. \\
& This reflection manages to conclude that ethics is always in gestation and reconfiguration depending on the new \\
demands of a global system, as a form of power that encourages resistance as a way of transposing the ethical & \\
devices that shape the behavior and habits of the subjects.
\end{tabular}

\section{RESUMEN}

\section{Palabras clave:}

Ética

Subjetividad

Política

Práctica
Hablar del "sujeto" y de la "ética" hoy debe partir de un lugar diferente o de un no-lugar que comprenda al sujeto en su devenir y transformación, identificándolo para reconocerlo, concibiéndolo como un sujeto en tránsito, un sujeto nómada, que puede ser reinventado en un ejercicio ético que sea reflejo de sí mismo y de sí misma, sin olvidar su constante encuentro con el otro. Este artículo de reflexión pretende hacer una comprensión y un recorrido por los desarrollos éticos, acercándose a una genealogía de los mismos. Asimismo, intenta relacionarse con la construcción de la subjetividad desde lo íntimo, lo público y lo privado, como modos de acción de lo ético en el sujeto y finalmente reflexionar sobre las transposiciones de una ética nómada dentro de las múltiples diásporas que permiten una visión de la ética moderna y la posibilidad en la configuración de los sujetos y sus subjetividades. Esta reflexión logra concluir que la ética está siempre en gestación y reconfiguración en función de las nuevas exigencias de un sistema global, como forma de poder que fomenta la resistencia como forma de transposición de los dispositivos éticos que configuran los comportamientos y hábitos de los sujetos.

\section{Introduction}

Ethics etymologically, it is derived from the Greek word ethos, which means "custom" and aims to give value in the act of human beings, that is, judges and values within qualifiers well or badly the behavior of men and women, thus framing the action from normality without possibility of deviation, therefore ethics has a close relationship with the Moral understood this as the practical and concrete aspect of the norms that man formulates and are accepted by society, his material object being human customs and behavior.

Therefore, in the genealogical and ethical journey, it is important to relate the poems of the homeric world that allude to the heroes, insofar as they raise the sanctioning elements and the teachings of these sanctioning actions. Some of them such as the Iliad, the Odyssey and Troy, of which it is not about reflection, but the works and performances 
of men, since through these first poems it begins to give the reconstruction of a first fabric of what is the ethos.

For Plato ethics is based on "virtue as knowledge and that it can be learned" (Diaz and Negrete, 2011, p. 23), that knowledge must be geared towards finding happiness (the supreme good - God), the calm of the soul and the development of personality and all this is acquired to the extent that acting is socially acceptable.

Otherwise, Agamben (2011) proposes that good must be given from works in a collective space arising from practice, proposing a formula with 3 elements: praxis + bien + polis $=$ Coexistence. Aristotle wondered what is the purpose that human beings should seek in the world: happiness, then ethics is a reflection on human action in search of freedom and for this we must try to develop the virtues, that is, the habits that help vi vir better. These virtues are situated in the world of human action.

Since the ethics of Nicómaco(De Aquino, Mallea. and Mendoza, 2001) the bet is a "Telos" (end), where an end, is an object work, it is a work of itself, which involves a series of repetitive actions that become habits that form a character, in Christian terms would call personality, but that for the current terms will be the constitution of a subjectivity, that is to say a constitution of itself as far as the truth I want to assume for me (Gamboa, Pérez and Izquierdo, 2012). Then between the end that is happiness and the constitution, there appear means (honours, pleasures and wealth), allow to attain happiness, but when the means become in short, the end is forgotten, at that moment the constitution of itself is lost as the subject of my constitution itself.

Another historical aspect or moment is the ethics of Christianity, which seeks to modify behaviors through its morality, transmitted by the commandments of God, to comply with the rules of the church. It is also mentioned in this medieval period that St. Augustine raises three types of morality, the social (the themes of the church), politics (the way in which the Roman Empire exercises the will of the people) and the moral of humanity.
The source of morality is aimed at the construction of a city of God, the subject will live in terms of the search for a good placed in God, which he only knows through sacred writing that ends up being the guiding object of the behavior of human behavior, that behavior the subject will know him through catechesis and the priest as a pastor who orders "his" flock, giving rise to a key element that is confession, which puts the subject to confess before another who has a power, power that allows him to deliver him from sin (Martinez, 2010, p. 43).

This medieval period organizes the subjects in space but also in time. Moral construction involves a theocentric construction, this is how the renaissance era is a break from medieval thought in terms of modern science, where the Aristotelian idea that the world is written in mathematical codes reappears and appears the idea that man is god on earth man is the measure of all things (Agamben, 2011).

Meanwhile, Protestant ethics, martin Luther appears who criticizes religious morals, adding that the use of men's morals is to seek to be righteous, while for John Calvin the moral life is a pure and holy action (Agamben, 2011). Martin Luther, on the other hand, proposes a reform of the Catholic Church as the only custodian of the faith, as the only valid interpreter of sacred scripture concerning the sacraments of the priesthood and confession. If sacred scripture is what says how I should direct my action then I can read the Bible, that implies that now it is "I" who can interpret my action and behavior in terms of the Bible and know what god's will is , therefore can now be directed as an individual, this implies a rupture in morality.

On the other hand, Machiavelli appears, who makes a reflection on politics and the state. It places religion according to politics, morality is incorporated as part of politics and power, and the church becomes an institution of state power, ruled by a monarchy. Machiavelli begins to show that politics is no longer the pursuit of the common good as was the case in the Greek world "the ideal of ethics and politics", politics then, at this time has become the art of staying in power and how to govern others (Agamben, 2011). 
Thus, the moment of reason as a source of morality in the modern age, is given the so-called Kantian ethic, in which Imanuel Kant, exposes, "Criticism of practical reason" and "Foundation of the metaphysics of customs", there, proposes that every ethic must be formal, that is, it must be universal and rational, valid for everyone, it should not say that it is what we should do, but we must act.

Another aspect of kantian ethics enunciated by Martínez (2010), is the concept of the moral value of an action, which lies in the motive that determines it, with a maxim that it poses, works in such a way that your behavior can be taken as a universal law. This maxim as a categorical imperative is part of the good is "good will". It is not that I propose that my action be universal, but that action is according to universal reason, that universal reason as Blanco (2012) would say configures of the modern subject, the obedient and regulated subject.

However, questions remain about this ethical journey, such as how far can Kantiano be, when following the universal reason the life of another is put at risk?", this opens up other ethical looks that break with the ideas of one reason, proposing new practices, situations and positions of the ethical subject, such as the look of the intimate public and the private, the ethical and political relationship and the Foucaulti and Rossi Braidotti proposals, as a conglomerate that offers different lenses of the ethical as subject configuration.

\section{The subjective configuration between the last, the private and the public}

Thinking about subjectivity in relation to intimacy brings us closer to the perspective of Pardo (1996), who raises that.

"intimacy is not the sum of particular preferences but their form, that is, their condition of possibility, so that this ternarying itself (...) does not mean firm sustenance not uncompromising or immovable rigidity but, on the contrary, designates an essential decadence" ( p.40).
Therefore, intimacy is seen as a daily experience of the existence that makes the subject to be on the brink of imbalance and balance, constant instability that dampens sense or better passion living, being the subject thrown into the world.

From this perspective delving into the seeds of intimacy does not imply explaining it because it would not make sense, you cannot impregnate only with denotations which is the way that some psychologists, sociologists and philosophers conceive and make use of intimacy "Intimacy does not it is made of sounds but of silences, we have no intimacy for what we say but for what we silence, because intimacy is what we silence when we speak" (Pardo, 1996, p. 55).

Therefore, intimacy rather than being a condition of language, appears as the effect of it, in what is said and in what is not said, intimacy is connotation rather than denotation, it is symbol, more than sign, it is meaning more than meaning. Intimacy feeds on the multiple interpretations it generates, as José Pardo (1996) would say "Intimacy does not make language possible - that's what the city is for - but it makes it real, it confers it being. Without intimacy there could be language, but no one could (besides that no one would) want to speak it" (p. 54), and in that effect the subjectivity is also configured that is also expressed in the silence of what we silence, that is, in intimacy. According to the author, misconceptions are given around the intimacy that threatens to destroy it to the extent that it has been mixed with the public and the private.

The first fallacy: of intimacy or identity. Intimacy is conceived as a source of public law and a source of general laws, the belief in natural law of human beings; has meant the linguistic expression of this fallacy, the idea that the word always has an original meaning, so that all the divergent meanings are deviations from that law. The consequence of this fallacy is the ruin of intimacy by making it a law of obligatory enforcement, that is to say that identity means that I have to comply with laws and therefore that privacy is lost, that is confused with that having myself (identity) it's not my intimacy but it's part of my identity. Intimacy made identity. 
In the second privacy fallacy, Pardo (1996) interprets the formula:

"man also has himself as if, himself, it were an attribute of the subject (private part of the individual), generating the confusion of intimacy with privacy, the consequence of the ruin of intimacy would be that it was conceived as a source of duty of compliance in the private", that is to say that, "in this case intimacy is ruined precisely by considering it as a source of rights (and therefore of duties) private" (Pardo, 1996, p.38).

Therefore, the linguistic expression of this fallacy lies in devising the intimate meaning of the word as if it were an explicit meaning (public but secret), the vice would be intimacy taken as private property. In this case the privacy would be taken as the secret, the hidden that could not be put outside. Intimacy is not always something secret or hidden, i.e. intimacy is continually explicit for the individual who is permanently unbalanced and has himself.

The third fallacy of ethnic cleansing or ineffability. He argues that intimacy is linguistically inexpressible: "If my intimacy is my deep and natural identity, which excludes other identities other than mine, my only possible relationship with others (those of a different nature than i) is violence and war, I can't talk to them because, if they don't feel what I feel when I say "I" we can never understand each other (Pardo, 1996), that if my intimacy I can't communicate, it's likely that a communication with the other can't be deployed.

The fourth fallacy is solipsism, which is defined by brown "as the idea that intimacy is radically incompatible and that it is only genuinely experienced in the absolute solitudes and isolation of social life" (Pardo, 1996, p.40), hence the intimacy would be lived by each individual and not shared with the other, because if they shared with someone they would lose their wealth.

From all of the above, it is evidenced that "having itself" does not indicate identity, nature, possession or property but tension, imbalance and restlessness (Pardo, 1996), that is, that man also has himself by his experiences ways of walking and living the world, within his difficulties, hopelessness and imbalances; that is why from all the above intimacy, is not balance, rigidity, or firm in itself, but the constant instability and failures that occur in your experience with the world, from yourself. To have intimacy is, to lack stable supports, to have fragility, exhaustions, is to be supported in false.

In order to contrast the above and avoid the banalization in which the use of intimacy has fallen, Pardo (1996) also proposes axioms or principles to speak of intimacy:

The first Axiom "to be someone to be inclined". Intimacy is not the sum of particular preferences but its form, that is, its condition of possibility, so that each one bends or lays and is of the particular concern of each one, his interests, searches, passions, desires, sensations and feelings. This constitutes the possibility of feeling life, detaching itself, that intimacy would be what puts us in constant imbalance, which leads to no absolute truths since we are always in imbalance by the different inclinations that are continually given.

The second Axiom "Intimacy, is the specifically human animality". It refers to this "is as own as its rationality." Man is notan animalbecause he expresses his emotions directly, immediately or brutally, nor because he encauses them by channels previously established by genetic or intrinsic patterns. The man feels his emotions, that is, the "hears ringing in that fold or interior in which he harbors himself, feels the bend or curvature through which his upright walk is always in unstable balance" (Pardo, 1996, p. 43).

Here, the intimate is interpreted as the part that characterizes the human being from the ability to listen internally, to hear the voices that each has within himself, or otherwise by way of comparison, "it is like the dark side of the heart when the poet finds the closet and is "the same" and several voices or personalities emerge" (Blanco, 2012), so it is considered to be there, where the emergence of new technologies that try to balance that imbalance in one way or another is given, since other technologies have been imposed that are apparently those of the "I" and 
that each assumes them himself, or as hypotheses those that are already given by biopolitical elements of control, which are so internalized in the subjects who believe them as their own. (Martínez, 2010).

The third Axiom Pardo (1996) states: "I stand by leaning on my inclinations" puts it as:"They are not only my ruin or doom, but also what makes me have myself, my guts and, therefore, what makes there are things that are endearing to me that can be endearing to someone"(p. 45). In this axiom there is a knowledge and recognition of my entrails, and consequently in contact with each other through the various ways of seeing the world through communication, that is, the recognition of one's limits of freedom and how far do these (chasms of doom), where the way to sustain themselves arises. Thus, by experimenting with one's own limits, inclinations, perversions, it is possible to self-compression to know how to master and learn to move recognizing the possibility of falling.

In this way, according to Martínez (2010) the questioning of how through these perversions can also generate domination to the other, taking up the statement made by Foucault, in relation to how in the practices of freedom an exercise in action on the other, not as an exercise of domination but how the other can resist, to the extent that the other has the freedom to decide, being the limits where the other is aware that what he does, in that sense implies my limits as the possibility of recognizing the limits of The other.

The fourth Axiom "Unconfessable Inclinations" Pardo (1996) states that: "My tastes and without flavors give me life, because they make me feel that I lose it, that I escape without me being able to do anything to retain it: those cries are the unconfessable inclinations (...) who reveal to me the mystery of my mortality, the truth of my own life, the truth of my own death".(p. 49). In this way the subject goes to his limits is known, and from there develops the life and feeling of each subject.

The fifth Axiom "The Intimate Truth of My Life Is His Falsehood", Pardo (1996) defines it as: "The falseness of my identity (I have myself, but I am not myself, I am not identical to myself) or my lack of nature. But all my concrete and unique weaknesses, beyond their moral evaluation, find their reason for being, their source, and their status of possibility in that essential weakness of my life. (p. 49). In the meantime, it can be pointed out that, the subject is nothing, to the extent that it has nothing defined, since it is always in constant construction.

The sixth Axiom "Having intimacy is not being able to identify", Pardo (1996) refers to intimacy as what prevents us from being identical, "to have intimacy is not to be able to identify with nothing. (...), I have no intimacy because I know who I am, but because I am the one for whom the meaning of the question Who am I never exhausted?" (p.50). In this way intimacy is understood as one that prevents us from being equal beings to others, that is to say that there is no identity but a continuous search for oneself.

In this way, in order to recognize the relationship between intimacy and subjectivity, it is stated that misunderstandings related to the intimate refer to the confusion of intimacy with privacy, which is necessary to undo. Delving into two misunderstandings, the first; he calls it the confusion of the private with the intimate, with these the first aporia: the private refers to the public.

In the meantime, the public is not the sum of private interests, since it cannot be total, that is, if everything is public nothing is, because it would give a totalitarian meaning, and the public alone is so, when its self-restriction constitutive, gives rise to the private, because it has to give part to the private and in turn by being public in the strict sense.

Intimacy is the experience of the public, they are not simply categories that relate as if they were separate entities, the public is one of the scenarios in what emerges significances and in which we put the interpretations that we elaborate in between ourselves or between us, like this:

intimacy is seen as the nudity of those who have no home, as vulnerability, in front of the other, condition of those of us who do not have a place of their own, which causes a second aporia to arise accordingly, in which one cannot speak of 
the intimate without referring to the common (Pardo, 1996, p.58).

For her part, Paula Sibilia defines intimacy as something that has a hidden meaning, protected by physical barriers such as the house called as private space and by moral barriers such as modesty, decorum and rectum, to expose her proposal of extimity and to talk about extimity, is to expose intimacy, to make public, intention that is linked to the different technological changes that have taken place in recent times, which causes a mistrust in the fact that there is a true intimacy (2008).

In this way social networks become the clearest show of extimity, to the extent in the "I" is defined by the look of the other, because nowadays it is essential to specify that I exist, because if I am alone and no one sees me, I have no guarantee that I exist" therefore the subject becomes a protagonist to exhibit, that is, that the subject is in constant change and can be another in different spaces and times, as a timely terrain to experiment and design new subjectivities (Sibilia, 2008). The author proposes that current subjectivity produces extimity where there was intimacy. Interiority has ceased to be the core of the truly human; what was written yesterday in an intimate journal is exposed today, on the web, to the obscene look of the whole. The model of the inner life is in crisis: the supposed truth of being was encrypted in that contact with one's own interiority, where modesty and secrecy dominated the scene, but today the stage is the screen where life is offered to the public, as a spectacle: it remains to know what happens to the one who observes, consumes and enjoys that public exposure of the other, both socially, individually and at the level of couples.

Thus, a first statement of Intimacy as a spectacle since Sibilia (2008), is the show of the self, which explains how the most influential media such as the Magazine Time, decide to make the small, ordinary and every day of ordinary people, defining the character of the year, "you", being the media (the internet), the mechanisms that promote the creativity of subjects for commercial purposes.
As a second statement the author expresses that he, i narrator and life as a story, it means that when the subject narrates or exposes his life to the different alternative means of communication, putting on a show of himself, exhibiting an invented intimacy, where their testimonies are false or not authentic, making a creation of the other self, which is not their self, so, that the meaning of the public and the private and the historical conceptions by which they have been traversed, according to Sibilia (2008) are disintegrating and demand new interpretations.

As a third aspect in terms of the private self and the decline of the public man; the author points out that:

The intimate and confessional writings demand ed or at least demand, the author's loneliness at the time of creating them, instead, the cybernetic versions of these accounts of themselves, on the other hand they are also usually solitary practices, although their disposition is rather more ambiguous, because they are installed at the limit of total advertising (Sibilia, 2008, p. $65)$.

This means that the person who writes, today, does so intimately solitary, but who then makes it public (a public display of intimacy), Sibilia (2008) proposes that, "between them thrive with incredible force the new modalities of writing intimate or extimity, but everything happens in real time: at the speed of the instant, which is simultaneous for all users of the planet"'(p. 68).

Fourth, in reference to the visible and the eclipse of interiority, it is exemplified as, the Western world undergoes serious transformations that influence the way individuals shape their subjective experiences, where they seek to project intimacy in the visibility of the screens, being the subjectivities introdirected (governed from the individual interiority, the intimate) dissolved, to accommodate the new alternating configurations (governed by the others and these in turn by the means of modernization and industrialization); as models of happiness, which 
impose a new form of modern subjectivity, of having to be me.

This culture of appearances, of spectacle, and of visibility, indicates reasons to seek the senses of self, such as "exhibitionist and performative tendencies that fuel the persecution of an effect: recognition in the eyes of others and, above all, the conditioned trophy to be seen"(Sibilia, 2008, p. 130).

As a fifth aspect (Sibilia, 2008) refers to the present self and instant subjectivity, which is based on the fact that both the display of intimacy and the spectacularization of personality, are phenomena that denote a certain displacement, around the modern subjectivities are built, revealing an abandonment of that inner locus (intimacy), towards a gradual externalization of the self.

Even the various media outlets that stage, the spectacle of the display of intimacy, are a greed, about everything that can refer to the real lives, both present and past, since the stories circulating in cyberspace, they do not seek to attain immortality in time, such as traditional narratives, but a celebrity or prominence at the time, which does not seek to transcend by its reflection, but instant visibility.

Sixth of this analysis the author and the cult of personality, represents the enormous $\operatorname{cog}$ that today communicates the cultural industry that, first of all, is a (Sibilia, 2008, p. 179) "machine of showing that for a long time, it is more powerful than any individual work to be exhibited". This gigantic exhibition and festival mechanism, with its commercial fuel and medium turbines, has become autonomous: it now works on its own and needs a constant but unimportant, nutrient-rich diet that is supplied in every season. The interesting thing is to do and above all to become visible. "Today, the powers of work are invested in themselves, in the devices that govern visibility" (Sibilia, 2008, p. 180)

In this way Foucault (1998) puts it, power games insist on transforming the acting self into a brand, when the personality of the speaker in demerit is more valued than what is said, in line, the increase of the figure of the author starring in the media, minimizes the work in the background and comes to justify its absence, putting his personality and private life in the foreground, indicating a new variation of the "author function"; so the new autographic practices of the Internet, and the phenomena of spectacular personality and display of the intimacy of "anyone" invaded all means.

Foucault (1998), also points out that the self and the author today can be anyone, you, or me, because by the influence of the media we are now all the personality of the moment, since marketing conquers the different scenarios of life at last for brands, destined for the franchise, in the emergence or conquest of the field of vision, appearing in the media (realities, contests on TV, internet, Twitter, blog and photolog), as personalities in these media to be visible. Similarly, the trend seems to be oriented to that daily life, has more creative power than the fiction itself that was handled before in the writings, since when the author is glamorous about his private life, it increases the sale of his books or visits to websites. Meanwhile, what is now desired is to exhibit the intimacy of anyone.

A seventh element is the real self and the crisis of fiction: "When daily life is more fictionalized and esterified with media resources, the more in view an authentic, true experience is sought other than a staging. You're looking for the real thing. Or at least something that seems so"(Sibilia, 2008, p. 220).

In modernity a demonstration is to know the intimacy of others, where the full rise of reality show, the spectacle of reality succeed, everything sells more if it is real; likewise the internet, is a scenario of this dynamic, with its spread of confessions revealed by a self, which insists on always being real; for the same reasons it has become common place to turn to fictional imaginaries to weave the narratives of everyday life, which generates a collection of stories that converge in the first person of the singular self.

Thus, the spectacularization of the self consists in transforming our personalities and lives no longer so private into fricted realities, which occur through cybernetics and popularize lives and personalities, between the world mediated by the real and not real, since through the sufferings and failures of the author who publishes, viewers see their own life reflected, 
constituting today frivolity and gossip seeking as a goal, to go beyond sales indices.

As the central thesis of this section Sibilia (2008) explains "that the relations between author and work, private life and public action, today are generalizing new narrative strategies, which denote other links between fiction and the real" (p. 224), itself, the same author notes that it is undoubtedly an interesting shift in the codes of realism: from those typical songs of the nineteenth century, to the home video clips, which are displayed on the internet"'(p.245).

Finally, as an eighth element is the character self and panic to loneliness, annotating the author who

That is why an image of itself is made: so that it is seen, exhibited and observed to cause effects on others. In an increasingly efficiency-oriented culture, any investigation into the root causes is often scorned, in order to focus all energies on producing certain effects on the perceptual detachment of others(Sibilia, 2008, p. 279).

According to the postulates described, it is clear that the contemporary world has laid its illusory foundations in the culture of spectacle and visibility, exerting daily pressure on bodies and subjectivities, facing certain ways of being in the world, so that subjects are projected according to new codes and rules, so that they are "compatible with the new gears, sociocultural, political and economic"(Sibilia, 2008, p. 279).

Moreover, this element of analysis allows to understand the gear of subjectivity, mediated by the control mechanisms (blogs, photologs, video logs and webcams, such as My Space, Twitter, Youtube, among others) that make themselves, believe sits the need to be visible and the idea of loneliness in terms of being recognized and seen by others within this cybernetic context traversed by the hidden and apparent logic of mercantilism.

This is ultimately based on the following paragraph:
Too often, perhaps no one looks at us What does it matter as then, if at some point we are good and beautiful, unique, singular, almost immortal? Or even if it's purely common like you and me. If no one sees us, in this context increasingly dominated by the logic of visibility, we might think that we simply were not. Or worse than we don't exist.(Sibilia, 2008, p. 298).

However, it is evident that the public space according to Martínez is the result of an interaction between games of truth, knowledge and power in which the subject is located, is located; that is, it finds a place through determinations of the demolished behaviors, for such interaction (2010).

In this way the subject is constituted morally according to the spaces, so fundamentally space is defined today and is a space in which the subject has to interact feeling also that it is separated, but also that it has a space, i.e. a space of its own that builds or that allows us to think that it has its own intimacy in relation to others, as Braidotti (2004) would say "public spaces as places of creativity reveal a paradox: they are fraught with significance and to the they are once deeply anonymous; are indifferent transitional spaces, but also inspiring meeting points" (p. 117).

Thus, public space becomes a discourse, which constitutes what the public means, being nothing more than an interaction between games of truth, knowledge and power; we can conclude that public space is nothing more than a construction, it is nothing more than a historical production that has made us think about the public.

The public space can be exemplified by a sauna where homosexuals are shared; in this sense there are a number of differences between what is intimacy to the body itself, where it interacts with other bodies, other bodies that are not yours and that are not a body of anyone. In this way it is possible to see how the public is also a construction.

The above scenario is a spatial form inaugurated by power relations that want to give the right place in the face of other human interactions, the appropriate place and that appropriate one understood under 
certain logics or as Foucault would say certain epitomes, devices and rationalities, which organize what men do, then public space is presented from the appropriate place, a suitable place for everything. Today's society has organized the places conducive or appropriate to certain human interactions, with the intention of controlling the subjects and protecting productivity and including them in the gear of the public.

It is a location of the subjects in a certain place so that it enters into a certain specific model of governmentality, which has been historically created; evidence of three moments the power of sovereignty, the power of discipline and the power of government; that is why one must ask about the space of the public and the private but also wonder about the space of the intimate which is nothing more than a discourse historically built of power relations.

But the question arises When does the individual become intimate? You could say that intimacy begins with the individual, we would have to think as a hypothesis, if it is with modernity that one begins to think of intimacy. And if we take what Paula Sibilia (2008) said, there is no space inside everything is outside because obviously the intimacy has to go out to the show. And there is the problem of human placement is where to locate the subjects.

It can be said that space is discourse but also physical place, organizes intimacy, constitute subjectivity. The subject appropriates some spaces and creates intimacy, this is the interesting thing to address if subjectivity is what I assume as truth, a discourse of intimacy; I assume it as a truth and about it I operate, that is, space of the intimate.

On the other hand, Arendt (2009), in his work the human condition refers that in ancient times the private retained his sense of the private devoid of the public, outside of which the being would not be fully human. The term intimacy was decunted before the Middle Ages, but with the advent of modern individualism it was possible to enrich the sense of the private by removing its feature of deprivation; therefore, "the modern private in its most appropriate function, that of protecting the intimate; was discovered as the opposite not to the political sphere but to the social sphere, with what is closest and genuinely related" (Arendt, 2009, p. 49). The moment the social invades the private the structures of government begin to have a function just like the family invading the private, and what we called private ceases to be private to become public.

Public according to Arend (2009), you can look from two perspectives in the first place means that everything that appears in the public can be seen and heard around the world, having the widest possible publicity. And the second look is that the public term means the world itself, in that it is common to all and differentiated from our privately-owned place. What makes it difficult to endure the masses is not the number of people or at least not in a real way, but the fact that among them the world has lost its power to group them together and separate them.

It should then be emphasized in the author's planted that The public-political sphere allowed all citizens to be seen and heard by all and enabled a common sphere, distinct from the private sphere. This sphere was the place where men could show their uniqueness through discourse and action, therefore, the private sphere was instead governed by necessity; because they were deprived of the presence of others, then it was the place that was privately owned, that is, a place of its own in the world and it was also the place where what needed to be hidden remained hidden.

In the Modern Age the distinction between the public and the private disappears with the rise of society, this means for Arendt (2009), the rise of the domestic whole or economic activities to the public sphere, what happened in the home and all the things that ant they belonged to the private sphere, now they have become public interest.

So the public is what is to be shown, how private what is to remain hidden, the modern age that Arendt speaks (2009) in his rebellion against society, has discovered how rich and diverse the sphere of the occult can be under the conditions of intimacy, that intimacy stripped of his meaning today, turned into that private that gives him the right to be public 
(information) by the relations of power, which they ask in return for their sacrifice, but these concepts or better categories will continue to be left in the hallways, in the corners, in the classrooms to try to give explanation but the true understanding is at the moment when we find ourselves in front of them and breathe us two meters from the face, at that moment it would be decided that both social, public, private or intimate is considered, when in every pore of existence is questioned Can privacy be held when you are being watched, monitored or controlled? Isn't there more privacy and publicity?

\section{Transitions between Ethics and Politics}

Aranguren (1968) presents the relationship between Ethics and Politics, raising four questions in the face of that relationship. The first has to do with political realism in which moralism is an idealism, and the ethical has a private sphere. There is no compatibility between the ethical and the political, therefore the aspirator to the political must do without the ethical.

The second question referred to by Aranguren (1968) also maintains the distance between the conjugation of the ethical and the political, but, unlike the first, ethics are chosen in this one; this mastery of ethics is due to the repudiation of the bad of politics and the variants of this position which are represented in a minimization of the State and in the abstention of all political activity or, at the very least, the limitation to participation in it.

The third position seeks to represent the relationship between ethics and politics in a tragic way, since this relationship is mediated by the tension between moral demand and political demand, without achieving the satisfaction of both. "The ethical is thus lived, in politics, as an insurmountable and therefore tragic impossibility. Man has to be moral; he also has to be political, and he cannot be a political one. There's no way out for him."(Aranguren, 1968, p. $65)$.

Aranguren's fourth position between the ethical and political is viewed differently from the previous three issues since not part of the assumption of "absolute impossibility", but of "the constitutive problematicity of the relationship between ethics and politics" (Aranguren, 1968, p. 65). Its main and most important characteristic is the tension that arises from the struggle for morality and political commitment, the latter seems to be the one that has the greatest possibility in the face of the compression of the relations between the ethical and the political.

The tensions evidenced in the four questions between ethics and politics create necessary tensions between morality actions and political representations, and create a moral awareness of political actions which reduces power repression and destruction that characterizes politics, without saying then that this moral aspiration that seeks the reduction of political power, does not produce a rejection by political power.

Aranguren (1968), he also seeks through his work fundamentally to highlight the role that politics plays in the state, he delves into the various modes of modern ethics that in his text he calls "individualistic ethics, ethics of alterity, and ethics of food" the author proposes a utopia of the state of justice, which is referred to as a state with radical insufficiency of ethics for good social order, this individualistic state has become what is often called social ethics.

By social ethics Aranguren (1968), he means that two different things must be understood in his words the ethics of alterity and the ethics of lightness, ethics of alterity since it seeks the moralization of society from the ethical-person, the plane of the wing, is the plane of objective social structures, giving rise to two forms of what it calls "technical institutionalization of the moral: the communist totalitarian state, which is total institutionalization, and the Welfare State, which is the institutionalization of the ethical-social.

In the face of the political Aranguren in Ethics and Politics, it proposes to highlight the role of politics and, moreover, its institutional dimension, of the State; the ethical trend and the political tendency are always manifested in tension and, often, in contradiction, however, the conjunction between 
ethics and politics is imperative, hence the difficulty in finding the balance between ethical attitude and political attitude which is lost as soon as they are absolutized.

Aranguren (1968), states that the role of the intellectual is critical and utopian and, the role of the politician is to be attentive to criticism and sensitive to utopia, he means that governing is something different from criticizing or dreaming; yet the political man, by obstinacy in performing the pure type of the "political animal", would break, on the other hand, on the reductionist side, the state of balance, the unstable conjunction of ethics and politics in the government of human society.

\section{New possibilities of ethics}

\section{Foucault and the Political Subject: Ethics and self- care as a practice of freedom.}

Foucault (1998) from the text, "the ethics of self-care as a reflexive practice of freedom", emphasizes the practices of freedom rather than liberation processes as necessary for society and politics, necessary to define valid forms and acceptable existence, i.e. "freedom is the ontological condition of ethics: but ethics is the thoughtful form that freedom takes" (Betancourt, Becker, \& Gomez, 1984). There the relationship of freedom is established as self-care.

Self-care is the way by which individual and civic freedom to some extent has been thought of as ethics, the Greeks stated that to conduct themselves well, to practice freedom properly, it was necessary to take care of themselves, to take care of whether, at the same time to know oneself, to train, to overcome himself; so in ancient times ethics as a reflexive practice of freedom, has turned in everything to the imperative of caring for itself, taking care of itself as the knowledge of rules of conduct or principles that are truths.

For Foucault the subject is not an essence, it is a form that is transformed and therefore the care of himself has a historical constitution that generates the formation of a type of subject immersed in real games. The practices of themselves constitute the subject and then a new ethics would be raised from playing with the minimum of domination that allows to base individual freedom (Martínez, 2010, p.72).

This is confirmed in "the hermeneutics of the subject" where Foucault (2005), states that "Ethics is the deliberate form that takes freedom", ethics is understood as an "instrument" to free the subject since ethics revolve around the techniques of subjecting, that is, to the care of self and ethics as self-care constitutes as an aesthetic of existence, as a work of art, the work of art that I myself can create with regard to my own existence, the care of itself, also implies a willingness to care for the other.

Thus, Martínez (2009) illustrates Foucault's ethical gamble as a practical possibility for subjects from a critical perspective that surpasses modern essentialism:

This critique is presented as the possibility of thinking about itself which discourses constitute the subjectivity itself to make the different articulations evident in the way we think, say and make our various ways of being. From this position, the subject is not something given, but is a way that has the possibility of continually modifying itself; therefore, knowing what discourses inhabit subjectivity is an ethical task (...) criticism will no longer seek formal structures that have universal value, rather it will become a historical search through the events that have given us led us to become subjects of what we do, we think, we say (p.32).

This proposes a critical work on ourselves not to allow others to be the sovereign of me, but this task is not individual, this refers to:

clarifying that self-care also implies a relationship with the other insofar as, in order to deal with it, it is necessary, at first, to listen to the lessons of a teacher, to guide knowledge of 
the truth and secondly, to develop interactions in a group, in which the deployment of individual freedom takes view. (Martínez, 2010, p. 83)

The ethics of self-care as a practice of freedom also require visibility into governance techniques, domination relations and strategic games which constitute forms of violation of rights and modes of exploitation.

\section{Transpositions on nomadic ethics}

When talking about nomadic ethics, the first task is to understand the meaning and problematization that Braidotti (2009), in his work "Transpositions of a Nomadic Ethics" makes ethics as a transformative form, fmarking it within a world determined by mercantilism, communication technologies and biotechnologies, as forms of power over subjects, which establish their conduct and habits, as forms of fragmentation and dispersal.

The Ethics for Braidotti (2009), is the discourse on the forces, desires and values that act as the empowering modes of being, while Moral is the set of established rules, therefore, this different way of thinking ethics causes the value systems with which we are accustomed to define ourselves, also invites us to map our incorporated and corporatized positions, where ethics must be assumed as political action, rhizomatic and nomadic.

In the meantime, nomadic ethics reject moral universalism and elaborate a different idea of ethical responsibility, in the sense of a fundamental reconfiguration of our being, in a world mediated by technology. It proposes the possibility of a sustainable ethic in relation to interconnection with oneself and others, implies a new way of combining one's own interests with those of the well-being of the community; that is to say an ethic from the alterity, thought from the common good with the other, which guarantees the sustainability of ethics as a collective exercise. This would mean transposing moral debates.

Therefore, the nomadic subjectivity responds to the subject who is in the middle of the narratives that are aimed at recovering the traditional perspectives, unitary of the neoliberal model, in order to continue the passionate search for alternatives. That is, a nonunitary subject who is at the mercy of pressures that drive him simultaneously in many directions. That is why nomadic subjectivity, "is a disputed space of mutations that do not obey any technological directive, or any moral imperative, as a fragmented dispersed vision" (Braidotti, 2009, p. 20).

That is why nomadic subjectivity is the way to identify a line of flight, something that is equivalent to saying an alternative and creative space of becoming, that does not fall between the mobile/ immobile, resident/foreign, because the question is not to disdain the condition of the marginal, of the other others, and to find a more precise and complex location fora transformation of the terms of that political action. (Braidotti 2009).

By contrast, another element of analysis for the constitution of nomadic ethics is to transpose the difference. Where transpositions arise from the "becoming" that occurs from the social transformations induced by the market and technology, as an ethic that reflects the complexity of today's realities.

When it comes to transposing the difference, it is proposed as a form of resistance from the ethical implications of the formulation of the oppressed groups sustained by a dialogical system, based on the idea of taking care of all as a responsibility collective, community and each other. The challenge is to "decentralize dogmatic, hegemonic and exclusionary power structures at the very heart of the dominant subject's identity structures, through rhizomatic interventions; presenting a vision the subject that envisions changes in structures". (Braidotti, 2009, p. 122).

However, the transposition seeks a new global ethic, in which a transformation is generated by the subjects, through the reconfiguration, that is to say loss of "disidentification" habits, which implies a practice of freedom, in the words of Braidotti (2009), it involves moving beyond pain, overcoming them is the ethical, that is the condition of the transformation of ethics. 


\section{What is Transpose to subject?}

For Braidotti (2004), the nomadic becomings, are the positive structure of difference, understood as a complex process of multiple transformations (Multiple becomings), a becoming refers to completely emptying themselves, opening it to the encounter with the exterior, this becomes a whole torrent of linked data and affectivity, which expel itself from the black hole of its isolation.

By transposing the subject, it becomes possible to transfer negative passions into positive ones, by drawing up suffering, bearing witness to receiving and containing the pain of others, and reconstructing ethical action through the ruins of hope. And then the question arises as to whether resilience is then a transmutation of the subject? it is said that in it the subject despite the pain returns to the logics of production, it is then proposed that resilience must receive, live and recognize pain and then enhance it without meaning that it must enter the logics of the market, people must have the option to choose the best for them.

Therefore, Braidotti (2009), aims to make ethics a practice of freedom, as opposed to the proposal of universalism that directs and establishes how we must all act, and is determined by structural parameters, while the transposition is to leave those structural parameters based on freedom practices, to go to the global, as a way of becoming against that moral system. What we call global is in the conditions of the territory, globalization leads to production logics, Peter Sloterdijk (2009), raises its opposition to these logics, and refers that global ethics is not a maximum of a New Yorker, it is to recognize conditions global response.

Therefore, the subject from this nomadic perspective prepares to withstand the impact of that afivity committed; the subject isolates or captures, a fact that is possible when the subject takes the form of a sustainable model of an affective, depersonalized and very receptive subject. This transposition mobilizes the individual ability to feel, experiment, process and withstand the impact of the complex materiality of the outside.
Spinoza also envisions ethics as a policy of resistance with a strong aesthetic component; Spinosian materialism places shared imagination and desires at the heart of itself (cited by Braidotti, 2004), all passions are external and collective to the extent that they engage others. According to Negri and Hardt (2002), the crowd as a collective social subject that reaches its legal form in a democracy. This is the most revolutionary aspect of Spinoza, who points to the gap between the metaphysical structure of the subject as the freedom agent and the order of capitalist production.

Spinoza argues that truth has its own need and that freedom consists of the will to accept it; it also refers to affection as the most powerful knowledge in that it ensures the compression of one's being. The affectivity is understood by Spinoza as intrinsically positive, is the force that tries to satisfy the capacity of interaction and freedom of the subject, that is the conatus or potential of the subject, that is, ethical behavior confirms, facilitates and intensifies the potential of the subject as the ability to express his freedom.

In this sense Dussel (2006), in the text "Twenty times political" works the concept of potentias and potenties, and considers this concept in political terms, for the political being is conceived as the one who knows how to obey the voice of the people. This conception relates to the Aymara's orientations of good living and what Sloterdijk raised (2003), in his texts of "Spheres" where one is not one, one is three, his placenta, you and his soul. According to these claims, what modernity has done is to bring the individual blindfolded, unaware of the relationship with the whole.

For Spinoza, this issue becomes a temporal dimension, an ethics of sustainability that is maintained through affection, which allows the subject to be maintained, longer or persist; then nomadic sustainability is defined in terms of becoming. Bodies are not passive entities but contain their own forces and try to connect with them. Consciousness in perspective means that the limits of my body are the limits of my consciousness. 
As for the policy Spinoza in Braidotti (2006), it is based on the relationship between freedom and the ethical ability to discern good from evil. For Braidotti the Spinocistic Ethics - deleuziana of nomadic subjectivity:

It does not deny the process of subjection but places it far from liberal individualism, from a vision of the collective and activity-oriented extreme subject. At this point there is the articulation of the ethical with the political, because in the ethical processes when the populations called minorities join, a subject transposition is generated that then represents a political implication, a fact that has a meaning important, it means, to be heard, to have another position, becoming a becoming in the face of the globalized world. (p. 208)

It should be noted then that nomadic ethics occur within a monistic ontology that sees subjects as modes of individualization within a common Zoé Flow. Is this kind of ethics questioned and wondering why a body can do in the search for active ways to potentialize itself through experimentation? at this point, the non-individualistic view of the subject as an entity incorporated into its means for it is affective and interrelated, but fundamentally social. The ethical question is to find a balance point, the historical context makes it difficult to detect the thresholds of sustainability to the boundary markers. With regard to the field of susceptibility transformer forces, sensitivity and availability to changes or transformations, in this sense Braidotti (2009), refers to the ability of the subject to withstand vicissitudes without breaking.

Braidotti (2004), closes referring to the question that ethical life pursues what improves and strengthens the subject without referring to transcendental values but by emphasizing the awareness of the interconnection of each other; the future processes seek to transform negative passions into positive passions through the power of a compression that no longer contends with the set of phallogocentric norms but is nomadic and affective.
In theprocess of transposing the subject Braidotti (2009), he takes memory and imagination and refers to Lloyd who argues that the fact that the mind and body can act as synchronized entities is due to the body's ability to remember sensations of traces and experiences, even after its immediate activity has calmed down. The corporatized subject is also characterized by the ability to discern similarities and experiences, between different experiences traces and sensations, being the subject of a social nature the affectivity as imagination acquires an importance Special.

While imagination can blindly attack affectivity and dreams, it is also the indispensable force that makes human reason able to install connections and establish links, marks a critical lack of judgment resulting from existing restrictions on faculty of rational thought. You can read two sides of the Imagination the negative that has been much discussed that allows the creation of networks in permanent expansion of associations and interconnections and the positive allows you to self-corporatized can be understood as Conatus (power) and act according to your desire to grow and increase your degrees of activity.

However, being affective or affective entity means being connected to life and therefore being immersed in affections emotions and passions. Ethics is to understand that we share a common nature, at the same time the concern for the individuals around us and for that very reason to be able to transcend self-interest by caring for others.

In this way an ethic of sustainability is based on temporality and persistence, which is equivalent to saying a nomadic compression of memory; remembering according to the nomadic mode requires composing, selecting and dosing, providing the conditions for deploying affirmative forces. Remembering the nomadic way means constantly searching for moments to maintain balance.

The ethics of sexual difference and the ethics of nomadic subjectivity are two sides of the same coin that Braidotti (2004) refers to the subject of becoming, immanent incarnate, for whom life is incorporated, corporatized and eroticized. 
Braidotti (2004), takes Deluze's theory and Irigaray's theory relates his theories and defines that subjectivity is the effect of a process, an itinerary that has no predetermined destination, virtual subjects to become. It places the universal in a transversal way in the uniqueness of the interrelationships between subjects collectively committed in the expression and realization of their potential this intersubjective space is a laboratory of becoming. Deluze and Irigaray agree that the subject is a body human entity sensitive flesh framed by skin.

It refers to the philosophy of levines and the Buddhaism typical of Judaism levines makes a defense to caress as erotic respectful contact with the skin of another is the basis of the haptic gaze (from Greek hapticus able to perceive) and the basis of sexual difference; and Bataille theorizes the idea that violence is inevitable transcendence that ontologically demands the consumption of the body.

The model of ethics proposed by these philosophies descendants of nomadism imply a non-hierarchical idea of transcendence this has implications for the notion of desire understood as potential.

In this case the potentia is the desire in the female body hood, referring to that it is at stake and not the feminine related to what was raised by the patriarchal phallogocentric code, but the feminine as a project, as a movement of destabilization of identity and therefore as becoming. "Virtual Feminism" as the realization of the female powers that are at the margins of the dominant current, Braidotti (2004), connects it to the social and symbolic project of the redefinition of female subjectivity, adds that it is a common feature of the nomadic feminists who, for them, sexual difference is not a problem.

On the other hand, Braidotti (2009), in transposing death, takes the concept of pain defines it not only as an obstacle but also as an incentive to produce an ethic of change and transformation. In the ethics of nomadic subjects there are unhealthy states which kill the affirmative powers of expression of positive passions (Potential), that is, they are not sustainable and do not endure.
The ethics in this transposing are related to a new disembodied becoming not with new revelations, but to extending the thresholds of sustainability. Ethics is a matter of experimentation, not control through social alignment techniques. The ethics of sustainability try to turn those processes into productive events that broaden the meaning of life.

Finally, under this idea the limits are those of one's own resistance in the sense of duration in time and of enduring the pain of confronting life in its facet of Zoe. The ethical subject is one who can withstand a confrontation, crack a little but without letting this destroy his physical or affective intensity; ethics consists of reworking pain and transforming it into Sustainability Thresholds, breaking and still sustaining, then Ethics is a thin sweep against the possibility of extinction. It is a way of making sustainable forms of transformation.

\section{Conclusions}

Ethics is an important element in the configuration of subjectivities, since it is through morality that subjects are induced to a notion of truth and practice in the world, through behaviors and behaviors determined in a global framework. That is why the new possibilities of ethics are framed to go in contrast to the ethical paradigms of universalization that have been perpetuated in the subject under an ethical basis, which induces them to commodify life in all its contexts, from devices that implanted in the lives of subjects.

However, the new looks of the ethical presuppose protocols that respond to practices of freedom, to the extent that there are other ways of thinking, saying and doing, from the constant configurations and temporal and conjunctural dynamics in the social environment, economic and political.

For this reason, the challenge is to make the discourses that constitute us, from the various narratives, because that is where other conceptions of ethics appear, since it changes the way in which subjectivity is configured, to the extent that new discourses are the ones that $\mathrm{v}$ constituting who we are. 
It is also identified that the areas of the public and the private have been little studied, particularly in the area of their linkage, particularly because regularly that both public and private are relatively recent conceptions in history, and that the discussion between the two areas had an eminently pragmaticpolitical origin, which appear to justify the appearance of the State as opposed to the actions of civil society, when in fact both dimensions represent simply aspects of the same integral phenomenon in which the subject is framed.

\section{References}

Agamben, G (2011). ¿Qué es un dispositivo? Revista Sociológica, 26 (73), 249 - 264.

Aranguren, J. L. (1968). Ética y Política. Madrid.

Arendt H. (2009). La esfera pública y la privada. Barcelona: Paídos.

Betancourt, R. F., Becker, H. y Gomez, A. (1984). La ética del cuiado de sí como práctica reflexiva de libertad. Revistas Concordia, 96-116.

Blanco, E. (2012). El cuidado de si en el escenario escolar: tecnologias del yo en la escuela y resistencia escolar. Bogotá.

Braidotti, R. (2004). El ciberfeminismo con una diferencia. Barcelona: Gedisa.

De Aquino, T., Mallea, A. y Mendoza, C. (2001). Comentario a la Ética a Nicómaco de Aristóteles. Eunsa.

Díaz , E. y Negrete , J. A. (2001). La filosofia de platón. Argentina: Editorial Manuscritos.

Dussel, E. (2006). 20 tesis de Politica. México: Editorial Siglo XXI.

Foucault, M. (1988). El sujeto y el poder. Revista mexicana de sociología, 50(3), 3-20. Recuperado de https://www.jstor.org/ stable/3540551?seq=1\#page_scan_tab_ contents

Foucault, M. (1994). Pourquoi étudier le pouvoir: la question du sujet.

Foucault, M. (2005). La hermeneutica del sujeto. France: Ediciones Akal.
Gamboa, A., Pérez, R. e Izquierdo, T. (2012). Formación humanística en educación superior: la ética en la Ingeniería de Minas. Bogotá: Ecoe. Martinez, J. (2009). Miradas sobre la subjetividad. Bogotá: Universidad de la Salle.

Martínez, J. (2010). La universidad productora de productores: entre biopolítica y subjetividad. Bogotá: Universidad de la Salle.

Negri, A. y Hardt, M. (2002). Imperio. Buenos Aires: Paidos.

Pardo, J. L. (1996). La intimidad. Valencia: Pretextos.

Sibilia, P. (2008). La íntimidad como espectáculo. Buenos aires: Fondo de Cultura Económica.

Sloterdijk, P. (2003). Crítica de la razón cínica (Vol. 23). Siruela.

Sloterdijk, R. (2009). Transposiciones sobre la ética nómada. Barcelona: Gedisa. 